\title{
PSEN1 p.Thr116Ile Variant in Two Korean Families with Young Onset Alzheimer's Disease
}

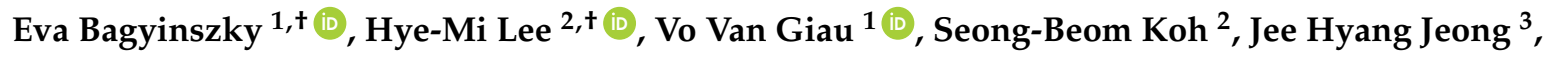 \\ Seong Soo A. An ${ }^{1, *}$ and SangYun Kim ${ }^{4, *}$ \\ 1 Department of Bionano Technology, Gachon University, Sungnam 13120, Korea; \\ navigator120@gmail.com (E.B.); giauvvo@gmail.com (V.V.G.) \\ 2 Department of Neurology, Korea University Guro Hosipital, Korea University, Seoul 08308, Korea; \\ platina84@naver.com (H.-M.L.); seongbeom.koh@gmail.com (S.-B.K.) \\ 3 Department of Neurology, Ewha Womans University Mokdong Hospital, Ewha Womans University, \\ Seoul 07985, Korea; jjeong@ewha.ac.kr \\ 4 Department of Neurology, Seoul National University College of Medicine \& Neurocognitive Behavior \\ Center, Seoul National University Bundang Hospital, Sungnam 13620, Korea \\ * Correspondence: seongaan@gachon.ac.kr (S.S.A.A.); neuroksy@snu.ac.kr (S.Y.K.); \\ Tel.: +82-317-508-755 (S.S.A.A.); +82-317-877-462 (S.Y.K.); Fax: +82-750-875-5 (S.S.A.A.) \\ + These authors contributed equally to this work.
}

Received: 3 August 2018; Accepted: 29 August 2018; Published: 2 September 2018

\begin{abstract}
An in depth study of PSEN1 mutation p.Thr116Ile (c.335C $>$ T) is presented from two Korean families with autosomal dominant inheritance. Clinical manifestation of our patients included memory loss, attention deficits, visuospatial dysfunction, agnosia, aphasia, apraxia, and personality changes, which occurred in their 30s. PSEN1 Thr116Ile was initially discovered in an Italian patient and two French families with early onset Alzheimer's disease (EOAD) with similar age of onset. To verify the possible pathogenic mechanisms of mutation, in silico predictions and 3D modeling were performed. Structure predictions revealed significant aberrations in first hydrophilic loop (HL-I loop). The hydrophobic isoleucine could alter the loop orientation through increased hydrophobic contacts with the surrounding amino acids. Mutation could destroy a possible hydrogen bond between tyrosine 115 and threonine 116, which may affect the loop conformation. HL-I was confirmed as a conservative region of PSEN1, which may be critical in PSEN1 functions. An additional pathogenic mutation, PSEN1 Thr116Asn, was also found for the same residue, where the patient presented young onset AD (YOND). Other mutations in HL-I loop, such as Tyr115His and Glu120Asp, were described in patients with YOND, supporting the critical role of HL-I loop in PSEN1 activity.
\end{abstract}

Keywords: young onset Alzheimer's dementia; familial; presenilin-1; mutation; PSEN1 Thr116Ile mutation

\section{Introduction}

Minority (5-15\%) of all Alzheimer's disease (AD) cases could occur under 65 years old, called early onset $\mathrm{AD}$ (EOAD), and even fewer $\mathrm{AD}$ patients are reported below 45 years old, called young onset $\mathrm{AD}$ (YOAD). Three genes were identified to be involved in EOAD/YOAD: amyloid prescursonr protein (APP, OMIM: 104760) on chromosome 21, presenilin 1 (PSEN1, OMIM: 104311) on chromosome 14, and presenlin 2 (PSEN2, OMIM: 600759) on chromosome 1. APP is a 770-amino acid-long protein, which contains the cleavage sites of $\gamma$ and $\beta$ secretase enzymes. PSEN1 and PSEN2 proteins are catalytic components of $\gamma$ secretase complex, and function as asparatyl proteases. They could play critical role the processing APP and the production of amyloid beta $(\mathrm{A} \beta)[1,2]$. Beside amyloid progression, additional possible factors may also play a significant role $\mathrm{AD}$ progression, for example 
immune deficiency or dysfunctions in autophagy system [1,3]. Most of these mutations in the above three genes presented an autosomal dominant inheritance pattern [1]. Interestingly, an autosomal recessive mutation, Ala673Val in APP gene, was also observed [4].

More than 200 mutations have been found in PSEN1 (http://www.alzforum.org/mutations). Majority of patients with PSEN1 mutations developed AD in their 40s and 50s. In addition, limited numbers of PSEN1 mutations were reported in younger AD patients below 40s or even under 30 years of age [1,5-8]. Presenilins are parts of $\gamma$ secretase complex, playing crucial roles in different neurological processes, such as synapse and memory formation and survival of neurons. Majority of PSEN1 mutations were associated with gain-of function pathogenic mechanisms [9], which could enhance the production of longer amyloid fragments, such as $\mathrm{A} \beta 42, \mathrm{~A} \beta 43$ or even $\mathrm{A} \beta 48$ [10]. Loss of PSEN1 function may also result in enhanced disease progression by reducing the activity of $\alpha$-secretase and the assembly of short amyloid peptide (A $\beta 40)$. Hence, increased and decreased productions of $A \beta 42$ and $A \beta 40$, respectively, would result in increased ratio of $A \beta 42 / A \beta 40$. In addition, decreased $A \beta 40$ levels in comparison to $A \beta 42$ may be associated with the different degree of $A \beta 42$ clearance, resulting an accumulation [9].

In this study, a PSEN1 Thr116Ile (c.335C>T) mutation was discovered in two Korean YOAD families for the first time in Asia. Next, bioinformatic analyses and in silico protein structural predictions were also performed for the mutation. PSEN1 Thr116Ile was previously reported in YOAD patients from Italy and France with similar age of onset in their 30s and 40s. All affected family members in the previous report and the current study developed disease symptoms with similar age of disease onset. Here, the clinical phenotypes of Korean patients are discussed in detail in comparison with the YOAD patients from Spain and France.

\section{Results}

\subsection{Genetic Analysis}

Sequencing showed a heterozygous C->T transition at codon 116 (g.73640282C $>$ T; c.335C $>$ T), leading to a threonine (ACC) to isoleucine (ATC) exchange for codon 116 (Figure 1a,b) of PSEN1. No additional pathogenic mutations were observed in APP or PSEN2 genes. SSCP also confirmed the presence of mutation (Figure 1c) from the different migration patterns between the mutation and wild type strains. PSEN1 Thr116Ile was missing ExAC and 1000Genomes databases. PSEN1 Thr116Ile was screened in the KRGDB database and was not present in healthy Koreans.

$$
\text { TA TAC C C CA T TCA A T A C C C C A T T C A }
$$

(a)

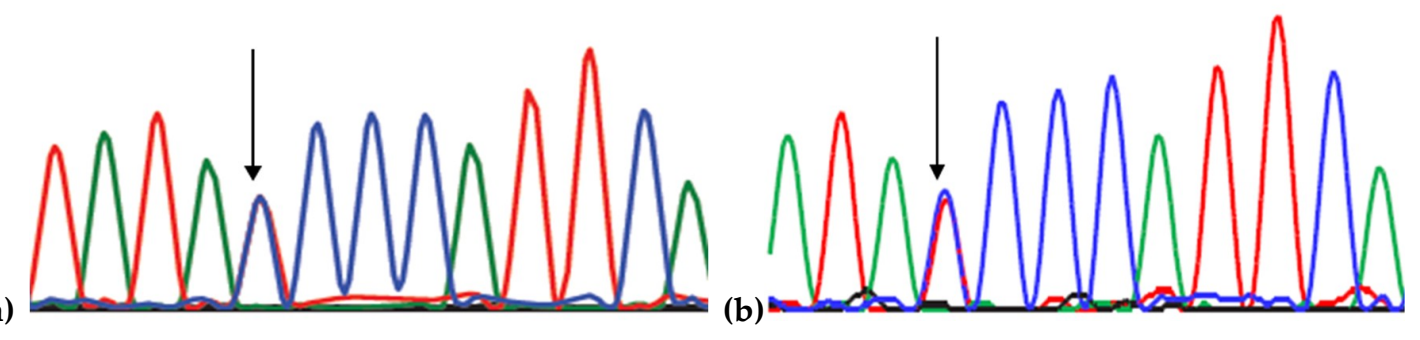

Figure 1. Cont. 


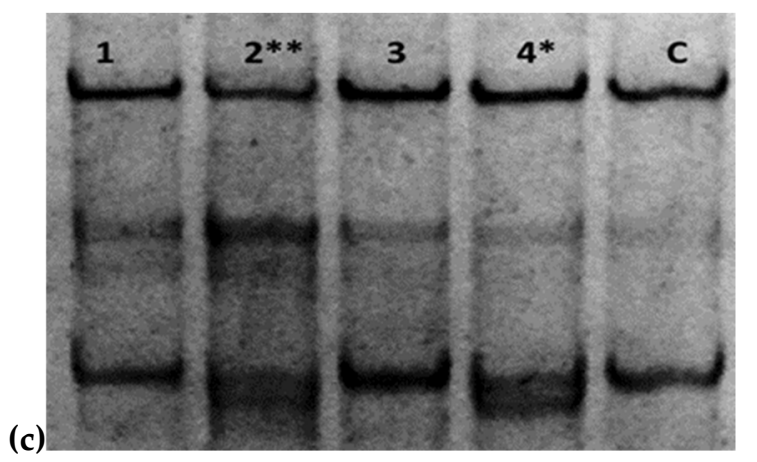

Figure 1. (a) Sequencing data of proband patient from Family 1 with PSEN1 T116I; (b) sequencing data of proband patient from Family 1 with PSEN1 T116I; and (c) SSCP data on PSEN1 T116I in Family 1 . Number $2^{* *}$ is the proband patient and Number $4^{*}$ is her affected sister. Numbers 1 and 3 are the asymptomatic and unaffected sisters. The "C" means the control band, a PCR product of an individual, who was verified as wild type for PSEN1 exon 5. Star means that these individuals are affected with mutation.

Three sisters of patient from Family 1 agreed to the genetic test, and one of her sisters (37 years of age at the time of genetic test) was positive for the mutation. The two other sisters (40 and 42 years at the time of genetic testing) did not show any phenotype of memory impairment, and they were negative for the mutation (Figure 1c).

\subsection{In Silico Predictions and $3 D$ Modeling}

PolyPhen2 revealed PSEN1 Thr116Ile as probably damaging mutation in both HumDiv and HumVar scores, 1 and 0.999, respectively. Multiple sequence alignment confirmed that Thr116 was a conserved residue in the PSEN-like protein sequences among vertebrates. However, SIFT suggested this mutation as "tolerated" mutation with the scores of 0.07. PROVEAN scores revealed the mutation as deleterious with the scores of -5.462 . ExPASY prediction suggested significant changes in hydrophobicity, bulkiness and polarity (Figure 2). Kyte and Doolittle hydrophobicity scores were increased significantly due to the mutation, from -0.022 (Thr116) to 0.556 (Ile116, Figure 2a). Bulkiness scores were also higher, changing from 17.513 (Thr116) to 18.139 (Ile116, Figure 2b). Polarity scores were decreased, from 7.722 (Thr116) to 7.344 (Ile116, Figure 2c). Changes in these parameters also affected the neighboring residues from residue 112 to residue 120 .
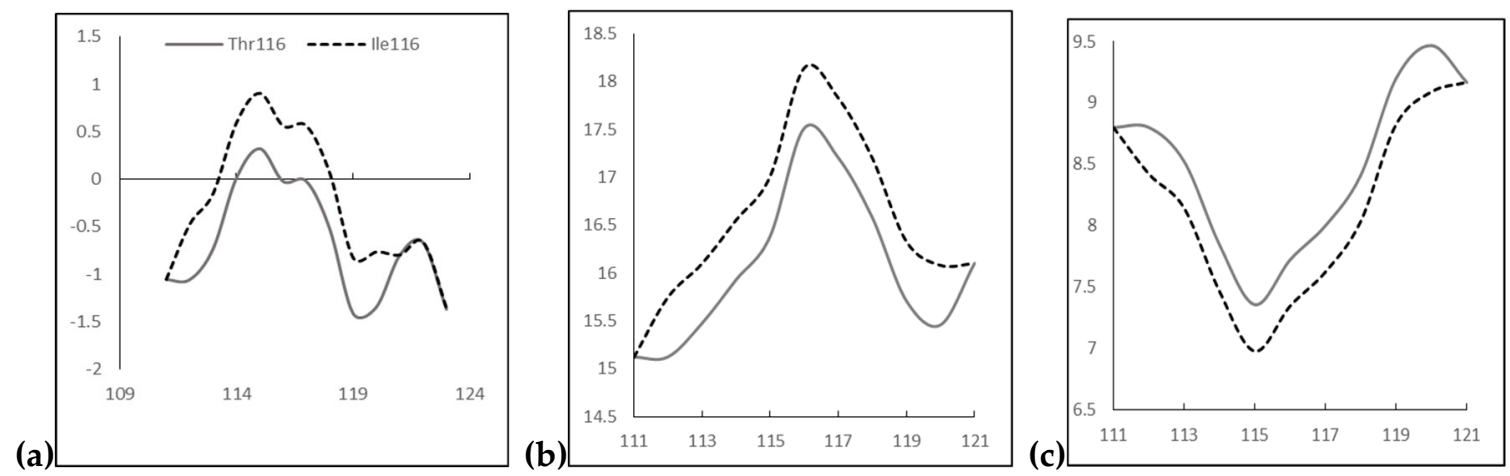

Figure 2. ExPASY prediction on PSEN T116I: (a) Kyte and Dootile hydrophobicity scores; (b) bulkiness scores; and (c) polarity scores.

The in silico 3D model on Thr116Ile revealed changes in the conformation of HL-I loop, which is known as a conservative region in PSEN1 (Figure 3). Orientation of threonine and isoleucine were 
also different. The altered conformation of HL-I may also affect the conformation of TM-II domain of PSEN1. Threonine is a hydrophilic amino acid, which is able to form hydrogen bond, since it has a hydroxy group, and the missing hydrogen bond may result in intermolecular changes inside the loop. In silico predictions revealed that the normal Thr116 could form hydrogen bound with Tyr115 and might be contacted by hydrophobic interactions with Pro117 (Figure 4a). In the case of Ile116, both contacts could disappear, and an additional hydrophobic interaction would be formed with Ile114 (Figure 4b).

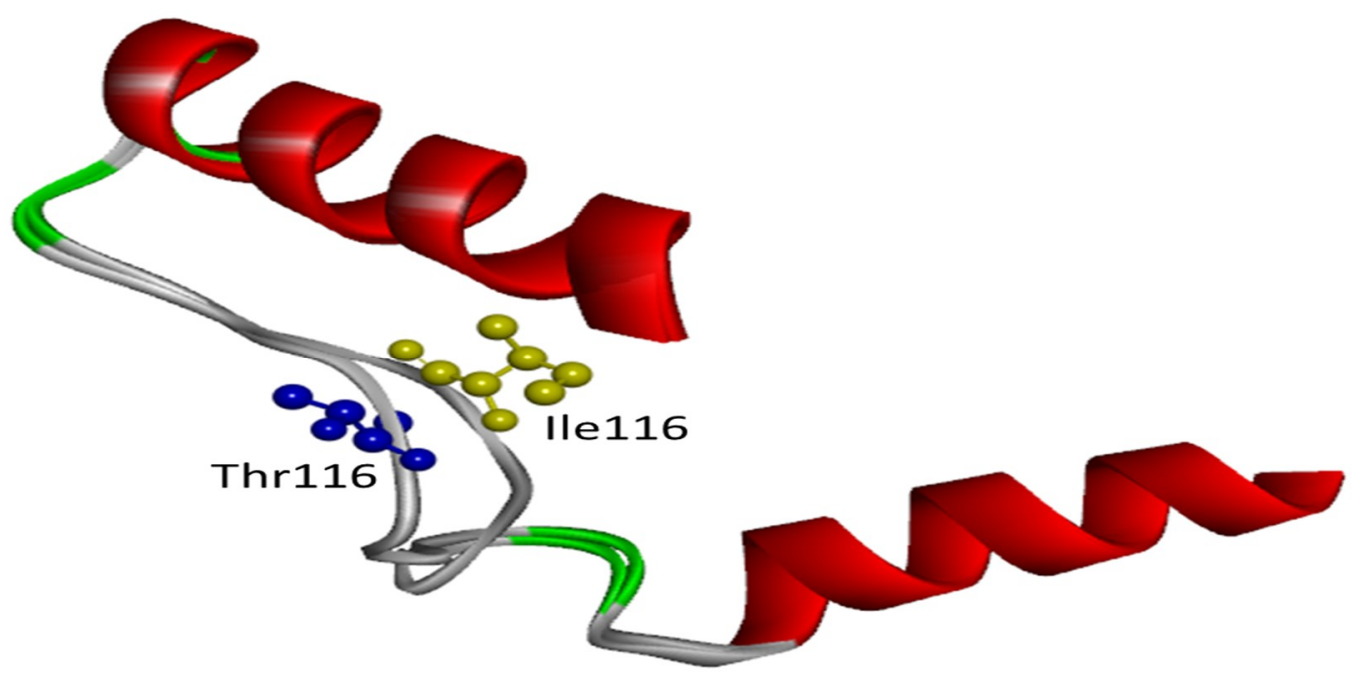

Figure 3. 3D modeling on PSEN1 Thr116Ile mutation, compared to the normal PSEN1. Threonine is labeled with blue while Isoleucine is labeled with yellow. Mutation could disturb significantly the HL-I loop structure.

(a)

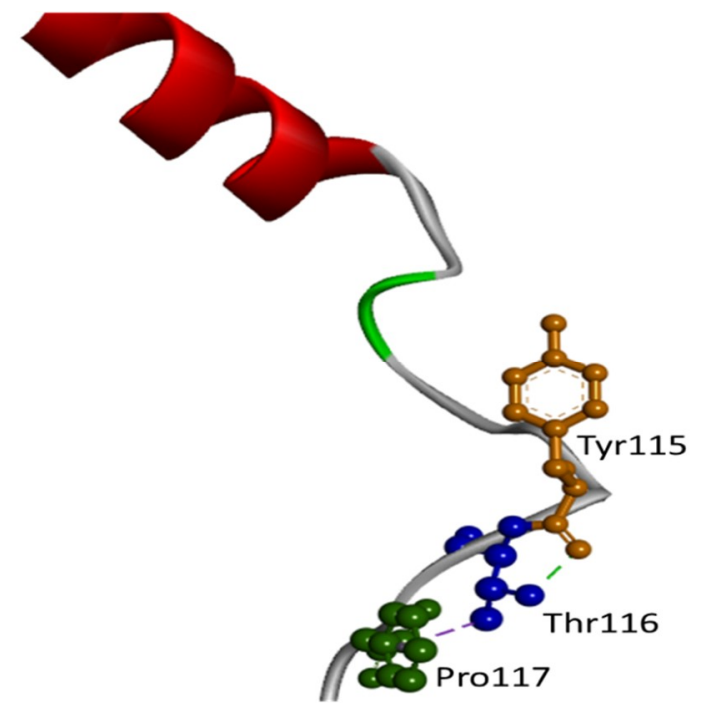

(b)

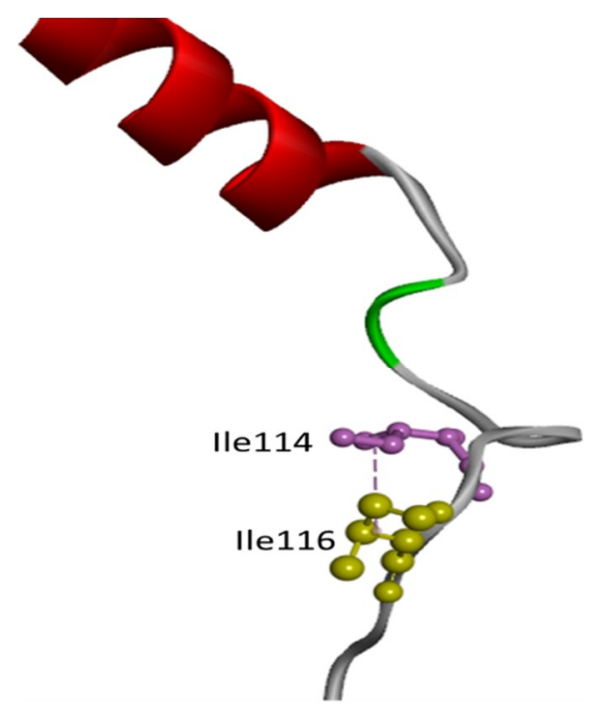

Figure 4. 3D model on PSEN1 Thr116Ile mutation, in terms intramolecular interactions. (a) Thr116 (blue) could form hydrogen bond with Tyr115 (orange) and may form hydrophobic interactions with Pro117 (green). (b) In the case of Ile116 (yellow), both contacts could be lost, and an additional hydrophobic interaction would be formed with Ile114 (purple). 


\section{Discussion}

In this study, a mutation (p.Thr116Ile) in PSEN1 was presented as cause of EOAD in two Korean families, which had not been described among Asian patients previously. The substitution from the hydrophilic threonine residue to the hydrophobic isoleucine residue might result in aberrations in the PSEN1 conformation. Both Korean patients with Thr116lle presented strong family history of disease, since several ancestors and relatives were affected with the disorder. In both patients, the disease progression started in their late 30s or early 40 s, and mild reduction could be seen in their MMSE scores (Table 1). MRI of patient from Family 1 revealed atrophy in the right temporal and parietal regions, and some vascular abnormality in the left frontal area. No significant atrophy was detected in patient from Family 2, but mild bitemporal hypometabolism was observed in FDG-PET (Table 1). In terms clinical symptoms, memory loss, visuospatial dysfunction and various neuropsychiatric symptoms, personality changes and speech disturbances were found in proband patient from Family 1. In proband patient of Family 2, memory loss appeared at the age of 37 [11], with altered mood and marked ideomotor apraxia.

Table 1. Comparison of EOAD cases, associated with PSEN1 T116I mutation.

\begin{tabular}{|c|c|c|c|c|c|}
\hline Case & First Case & Second Case & Third Case & Korean-1 & Korean-2 \\
\hline Country & Italy & France & France & Korea & Korea \\
\hline $\begin{array}{c}\text { Age of onset } \\
\text { (years) }\end{array}$ & 45 years & $40-47$ years & 38-44 years & 41 years & 38 years \\
\hline Disease & EOAD & EOAD & EOAD & EOAD & EOAD \\
\hline Imaging & $\begin{array}{l}\text { Atrophy and } \\
\text { fronto-parieto- } \\
\text { temporal } \\
\text { enlargement of } \\
\text { cortical sulci }\end{array}$ & NA & NA & $\begin{array}{l}\text { MRI: atrophy } \\
\text { in the right } \\
\text { temporal and } \\
\text { parietal regions } \\
\text { PET: NA }\end{array}$ & $\begin{array}{l}\text { MRI: Atrophy in } \\
\text { the medial region } \\
\text { PET: reduced } \\
\text { metabolism in } \\
\text { temporal and } \\
\text { parietal region }\end{array}$ \\
\hline MMSE & $14 / 30$ & NA & NA & $\begin{array}{c}\text { Initially } 24 / 30, \\
\text { later } 18 / 30\end{array}$ & $23 / 30$ \\
\hline $\begin{array}{l}\text { Clinical } \\
\text { phenotype }\end{array}$ & $\begin{array}{l}\text { Memory loss, } \\
\text { confusion and } \\
\text { disorientation, } \\
\text { followed by } \\
\text { progressive } \\
\text { memory loss }\end{array}$ & $\begin{array}{l}\text { No detailed } \\
\text { information, } \\
\text { but patients } \\
\text { fulfilled the } \\
\text { NINCDS-ADRDA } \\
\text { criteria }\end{array}$ & $\begin{array}{l}\text { No detailed } \\
\text { information }\end{array}$ & $\begin{array}{c}\text { Memory } \\
\text { impairment, } \\
\text { confusion, } \\
\text { visuospatial } \\
\text { dysfunction, } \\
\text { speech } \\
\text { disturbances. }\end{array}$ & $\begin{array}{l}\text { Impairment in } \\
\text { memory and mood, } \\
\text { marked ideomotor } \\
\text { apraxia }\end{array}$ \\
\hline Family history & Unknown & Familial & $\begin{array}{c}\text { Probable } \\
\text { familial }\end{array}$ & Familial & Familial \\
\hline References & [12] & [13] & [14] & Our data & Our data [11] \\
\hline
\end{tabular}

PSEN1 Thr116Ile was described initially by LaBella et al. (2004) in an early onset AD patient. The age of onset was 45 years, starting with forgetfulness, followed by memory loss, confusion and disorientation. Three-year history of progressive dementia could be seen in the patient. The exact family history remained unclear, since her grandmother and mother both died in their early 40s, but neither of their cause of death was associated with dementia (cancer and accident, respectively). Since the mutation was missing in 100 healthy non-related controls, it was suggested as a pathogenic mutation [12]. The second case of this mutation was reported by Raux et al. (2005) in four AD patients from the same family. Inheritance pattern was autosomal dominant, and the age of onset ranged 40-47 years. The NINCDS-ADRDA criteria confirmed that these patients had AD, but post-mortem analyses could not be performed [13]. A second French family was described by Wallon et al. (2012) in a large French study, where disease onset was 38-44 years of age. Disease duration could range $3-5$ years. No detailed clinical data were mentioned [14]. Similar to the previously described disease 
cases from Europe, the affected members from the two Korean families developed disease between 38 and 47 years of age. Rapidly progressive dementia appeared in these patients, and they died before 50 years of age.

An additional mutation was found for the same residue, Thr116Asn (Table 2), reported in an EOAD family in Denmark. Autopsy confirmed that neuropathology was consistent with AD diagnosis. Age of onset ranged 38-41 years. This mutation was associated with rapid progression of disease, since the duration from the first clinical symptoms to the death ranged 4-8 years. Earlier onset of disease (30-33 years) was observed in a French family, but there was no information on the clinical symptoms in this family [15].

Table 2. Comparison of PSEN1 Thr116Ile with Thr116Asn.

\begin{tabular}{ccc}
\hline Mutation & Thr116Asn & Thr116Ile \\
\hline Pathogenicity & Pathogenic & Pathogenic \\
\hline Age of onset & $\begin{array}{c}35-41 \text { years } \\
\text { (Familial) }\end{array}$ & $\begin{array}{c}40-47 \text { years } \\
\text { (Familial and de novo) }\end{array}$ \\
\hline Clinical phenotype & $\begin{array}{c}\text { EOAD } \\
\text { (no clinical data) }\end{array}$ & EOAD \\
\hline PolyPhen2 scores (HumDiv) & $\begin{array}{c}1.00 \\
\text { (probably damaging) }\end{array}$ & $\begin{array}{c}1.00 \\
\text { (probably damaging) }\end{array}$ \\
\hline SIFT scores & 0 (damaging) & 0.07 (tolerated) \\
\hline References & {$[12-14]$} & {$[15]$} \\
\hline
\end{tabular}

The hydrophilic loop (HL)-I is located between transmembrane (TM)-I and TM-II of PSEN1, and 18 mutations were observed in this region (Table 3 and Figure 5). The majority of them (19) were missense mutations. In addition, one splice site mutation was also reported, resulting in an insertion (Leu113_Ile114insT). Patients with these mutations usually developed AD, but one mutation, PSEN1 Leu113Pro, was associated with FTD [16]. Pathogenic nature of mutation Arg108Gln was refuted, since it co-existed with a known mutation in APP [17]. AD patients could present additional phenotypes too, such as Parkinsonsim (Pro105Leu) [18], myoclonic jerks (Arg108Gln, Leu113Pro, Tyr115His, Pro117Leu, Pro117Ser, snd Pro117Arg) [17,19-22], seizures (Leu113Gln, Leu113Pro, Tyr115His, and Pro117Leu) [17-20], language-behavioral impairments (such as Tyr105Cys and Glu120Asp) [21,22], ataxia (Pro117Ala) [21], or spastic paraparesis (Glu120Gly) [22]. Age of disease onset was usually under 60 years of age. In addition, several patients with some of these mutations (Leu113Pro, Tyr115Cys, Pro117Leu, Pro117Ser, and Glu120Gly) developed young onset AD under 40 years of age [17-19,22,23]. The majority of these residues were conserved, but PSEN1 Glu123Lys seemed to be not conserved in PSEN2 [24]. These mutations may prove that HL-I could be an important region in PSEN1. This loop is located in the lumen, and was found to be a highly conserved region in PSEN1 [12]. Gong et al. (2010) performed generated mutations in HL-I and TM-II regions of PSEN1, and confirmed that importance of these regions in $\gamma$ secretase activity. These domains may not be involved in $\gamma$ secretase complex formation, and in the recruitment to other components (APP, Notch or N-cadherin) to PSEN1 protein. Instead, they might play a critical role in the endoproteolysis and catalysis of $\gamma$ secretase substrates. In addition, HL-I and TM-II might be important in regulating the docked substrates to the enzyme [25]. Additional studies by Tagaki-Niidome et al. (2015) suggested that HL-I and the C-terminal may be important in the $\gamma$ and $\varepsilon$ cleavage. These two regions may play a critical role in substrate binding site in $\gamma$ secretase complex $[26,27]$. 
Table 3. Mutations, located in PSEN1 HL-I.

\begin{tabular}{|c|c|c|c|c|c|c|}
\hline Mutation & Dx & Clinical Symptoms/Pathology & Age of Onset & Family History & Functional Studies & References \\
\hline Phe105Cys & $\mathrm{AD}$ & Memory impairment and behavioral changes & $45-60$ years & Positive & NA & [28] \\
\hline Phe105Ile & $\mathrm{AD}$ & NA & $53-58$ years & Positive & NA & [19] \\
\hline Ple105Leu & $\mathrm{AD}$ & Parkinson's like symptoms, severe dementia & 52 years & Probable positive & NA & [18] \\
\hline Arg108Gln & $\mathrm{AD}$ & Progressive cognitive decline, myoclonic jerks & 45 years & Segregation could not proven & NA & [17] \\
\hline L113_I114insT & $\mathrm{AD}$ & Postmortem studies confirmed the AD & $34-45$ years & Familial & 3.4-fold higher $A \beta 42$ levels & [16] \\
\hline Leu113Pro & FTD & Behavioral impairments, myoclonic jerks, seizures & $38-50$ years & Familial & NA & [19] \\
\hline Leu113Gln & $\mathrm{AD}$ & $\begin{array}{l}\text { Rapid progressive dementia, drop attacks, } \\
\text { myoclonic seizures, and bilateral spasticity. }\end{array}$ & $33-36$ years & Familial & NA & [18] \\
\hline Tyr115Cys & $\mathrm{AD}$ & Postmortem studies confirmed the AD & $39-45$ years & Familial & 5.4-fold higher $A \beta 42$ levels & [21] \\
\hline Tyr115His & $\mathrm{AD}$ & Epileptic seizure, myoclonus & $35-40$ years & Familial & $\begin{array}{l}\text { Increased levels of } A \beta 42, \\
\text { lower } A \beta 40\end{array}$ & [29] \\
\hline Thr116Ile & \multirow{2}{*}{\multicolumn{6}{|c|}{ Was discussed in details in Tables 1 and 2}} \\
\hline Thr116Asn & & & & & & \\
\hline Pro117Ala & $\mathrm{AD}$ & Issues with balance, tremor, ataxia & 29-35 years & Familial & Elevated $A \beta 42 / 40$ ratio & [23] \\
\hline Pro117Leu & $\mathrm{AD}$ & $\begin{array}{l}\text { Progressive memory impairment, mood swings, } \\
\text { seizure, myoclonus }\end{array}$ & $24-33$ years & Familial/de novo & $\begin{array}{l}\text { Elevated A } \beta 42 \text {, inhibited } \\
\text { neural overgrowth }\end{array}$ & [20] \\
\hline Pro117Arg & $\mathrm{AD}$ & $\begin{array}{c}\text { Apathy, behavioral changes, seizures, myoclonus, } \\
\text { gait impairment }\end{array}$ & $33-36$ years & Unknown/ familial & Elevated total $\mathrm{A} \beta$ & [30] \\
\hline Pro117Ser & $\mathrm{AD}$ & $\begin{array}{l}\text { Personality changes, severe dementia, seizures, } \\
\text { myoclonus, tremor }\end{array}$ & 29-33 years & Familial & Elevated $A \beta 42$ levels & [31] \\
\hline Glu120Asp & $\mathrm{AD}$ & Language impairment, seizures, disorientation & $34-53$ years & Familial & NA & [22] \\
\hline Glu120Gly & $\mathrm{AD}$ & $\begin{array}{l}\text { Memory and cognitive decline, seizure, gait } \\
\text { disturbances }\end{array}$ & $30-39$ years & Familial & NA & [32] \\
\hline Glu120Lys & $\mathrm{AD}$ & Spastic paraparesis & $43-45$ years & Familial/ unknown & Elevated $A \beta 42 / 40$ ratio & {$[33,34]$} \\
\hline Glu123Lys & $\mathrm{AD}$ & Progressive aphasia, reduced visuospatial activity & $56-62$ years & Familial & NA & [24] \\
\hline
\end{tabular}




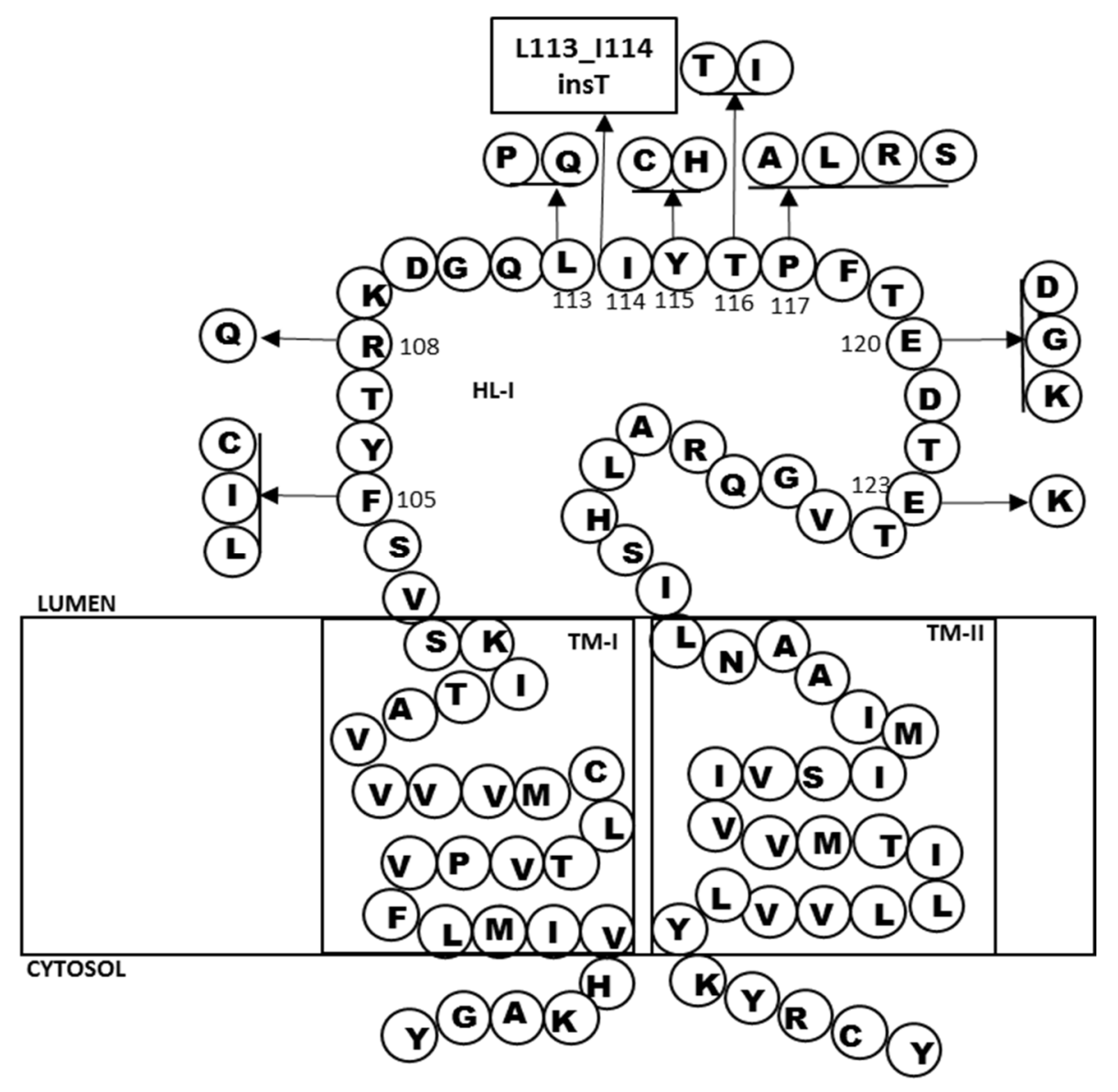

Figure 5. Mutations, located in the HL-I of PSEN1 protein.

Limitations of our study are that no in vitro studies could be performed to confirm how PSEN1 T116Ile could be involved in disease progression, since no CSF could be obtained in the patients, and biomarkers (A $\beta$, total Tau and phospho-Tau) could not be measured. In addition, since several of them refused the genetic test, segregation could not be proven even though inheritance seemed to be autosomal dominant in both families.

\section{Materials and Methods}

\subsection{AD Patients and Their Families}

\subsubsection{Family 1}

A 41-year-old woman (II-3, Figure 6a) visited the Korea University Guro Hospital with gradually impaired cognitive function over the previous three years. The first symptoms appeared at the age of 38 years when mild forgetfulness was described by her husband. She had managed a travel agency, but she dissolved the company because of impairment of episodic memory and poor concentration. Her memory problems became prominent progressively with personality changes. She denied any social history of substance abuse or toxin exposure. Her past medical history was otherwise negative for medical illnesses. Her family history revealed that her mother (I-8) died at the age of 44 without genetic analysis, after experiencing seven years of memory impairment, visuospatial dysfunction and various neuropsychiatric symptoms. In addition, her maternal aunt (I-3) and maternal uncle (I-7) also experienced severe cognitive impairment from their mid-30s. The proband patient was the third of five children, and her younger sister (II-5) also experienced memory problems without impairment of activities of daily living recently. The three sisters (II-2, II-4 and II-5) of patient agreed to undergo a 
screen for mutation, however, her currently asymptomatic brother (II-1) declined the genetic test or to provide any information on himself.

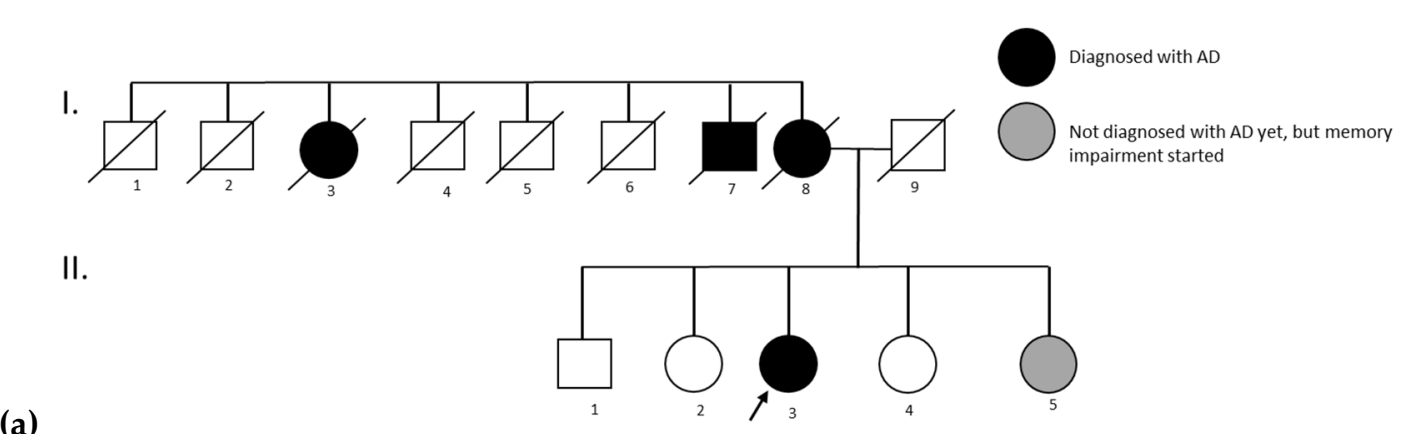

(a)

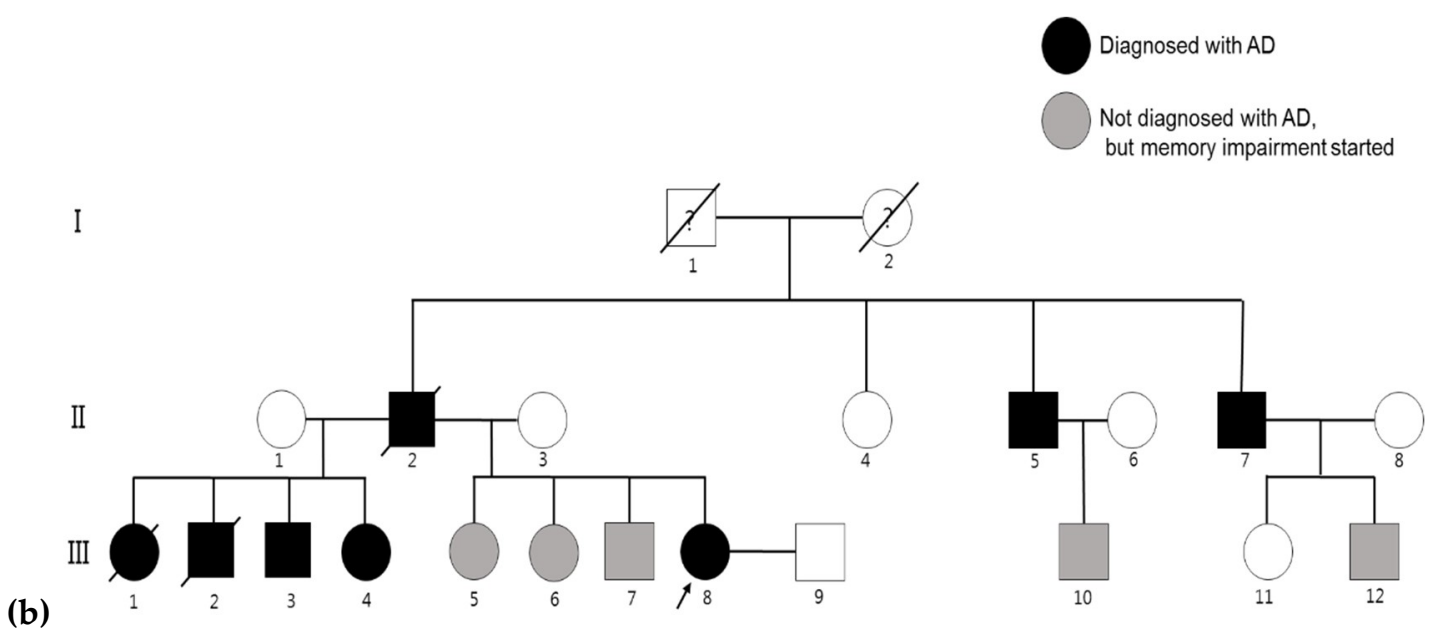

Figure 6. (a) Family tree of patient with PSEN1 T116I mutation (Family 1); and (b) family tree of patient with PSEN1 T116I mutation (Family 2). This figure was adapted and reprinted with the permission from Dove Medical Press (Clinical Interventions in Aging) [11]. White circles mean asymptomatic patients, which were not diagnosed with disease. Family members which were crossed out, already died. Arrows show the proband patient. Question mark at the grandparents means that their disease status is unclear.

Upon neurological examination, she showed slurred speech, mild ideomotor apraxia and impairment of short-term and long-term memory functions. Her Korean version of the mini-mental state examination (K-MMSE) score was 24/30, and global deterioration scale score was 3 (mild cognitive decline). Magnetic resonance imaging (MRI) of the brain revealed mild diffuse cortical atrophy. In the imaging data, atrophy could be seen in the right temporal and parietal regions. Vascular abnormalities also appeared in the left frontal area (Figure 7a). Laboratory screening was negative for vasculitic, metabolic, or infectious causes. Her symptoms gradually progressed, and there was no response to acetylcholine esterase inhibitor. After two years, her K-MMSE score was 18/30 and global deterioration scale score was 4 (moderate cognitive decline). At the age of 44 years, she became wheelchair-bound, and she was put in a dementia hospital. Blood samples for the genetic testing were collected from the proband patient. Subsequent DNA sequencings of her three sisters were also performed, and PSEN1 Thr116Ile mutation was found in her younger sister (II-5), and she already developed mild memory impairment. The currently asymptomatic sisters (II-2 and II-4) were negative for the mutation. After the genetic diagnosis of YOAD, she was monitored regularly. 

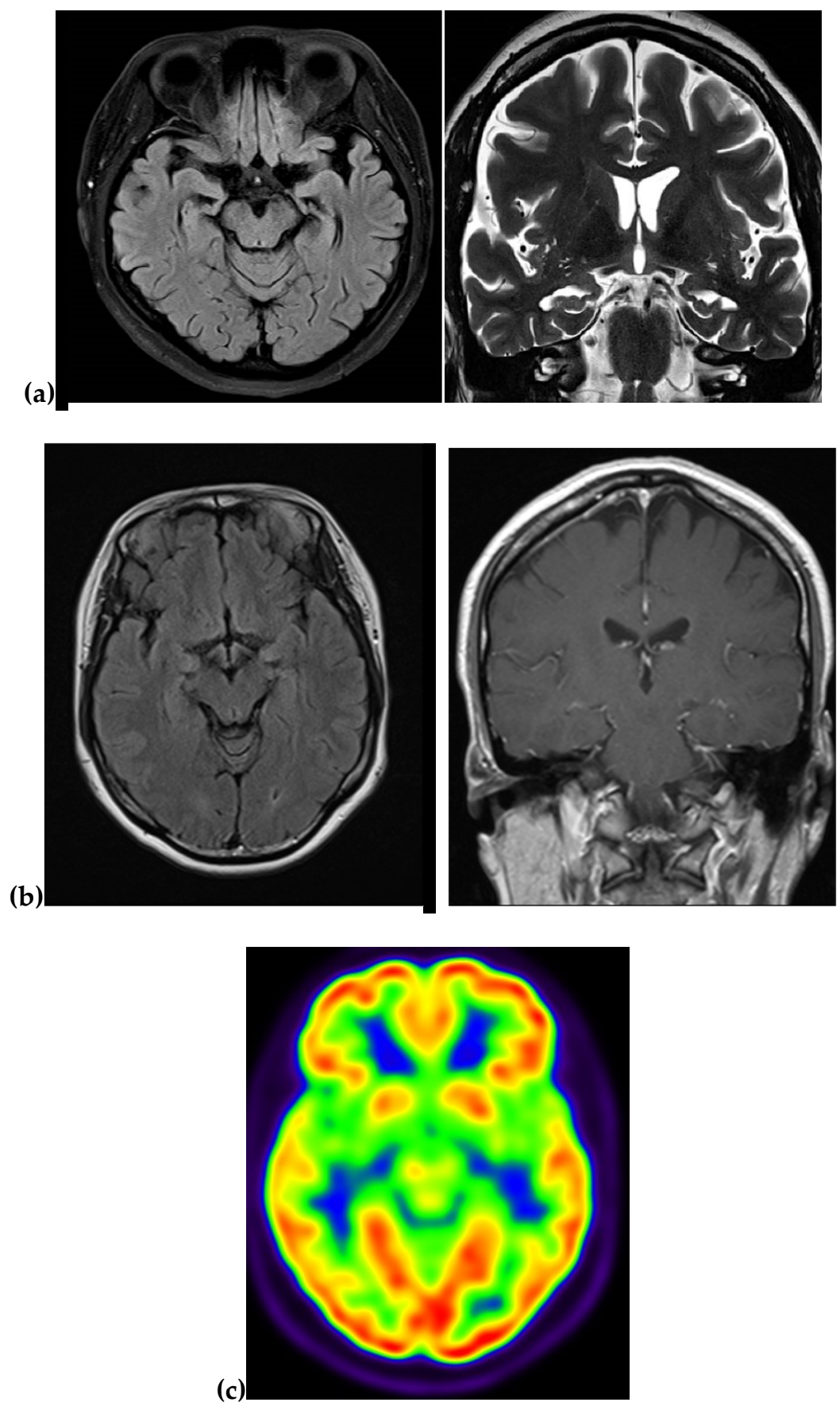

Figure 7. (a) MRI data of proband patient of Family 1. Atrophy could be seen in the right temporal and parietal regions. A vascular abnormality also appeared in the left frontal area. (b) MRI data of proband patient of Family 2. (c) PET data from Family 2.

\subsubsection{Family 2}

Proband patient was part of Clinical Research Center for Dementia of South Korea (CREDOS) project, which analyzed APP, PSEN1 and PSEN2 mutations in 100 EOAD patients. Clinical details and scientific predictions were not included in the previously reported study [11]. In this manuscript, a detailed description of this case with detailed clinical, imaging data, and structure prediction analyses are presented. A 43-year-old woman (II-8, Figure 6b) visited Ewha Woman's University Mokdong Hospital with the presentation of gradual cognitive dysfunction, which started at 36 years of age. Her first symptoms were mild forgetfulness, repeating same conversations and forgetting valuable 
objects. Recently, her memory impairment became worse, she could not remember when she had meal, eating several times a day, and who she had met or where she had been. Her mood also changed to apathetic because of her impairment from previous concern or worrying about herself. She was still able to manage household, taking care of her children, but the cleanliness diminished. She was a nutritionist at high school, but retired the year before the first visit. At neurological examination, she showed brisk deep tendon reflexes, especially in knee jerk and mild paratonia. Marked ideomotor apraxia was observed. Her Korean version of the mini-mental state examination (K-MMSE) score was $24 / 30$, clinical dementia rating scale was 0.5 (sum of boxes 2.5 ) and global deterioration scale score was 3 (mild cognitive decline), but showed moderate impairment of short-term and long-term memory function in detailed neuropsychological test. Her past medical history was negative for any medical illness, substance abuse or toxin exposure. Her family presented strong family history of dementia. No information was available on her grandparents, but his father (II-2) died at the age of 65, after experiencing 10 years of dementia. In addition, her paternal uncles (II-5 and II-7) also suffered from dementia from their mid-forties. Proband patient was the last of eight children from the two marriages of II-2. All of her older half-sisters and half-brothers (III-1, III-2, III-3, and III-4) suffered from dementia. Her siblings (III-5, III-6, and III-7) and her cousins (III-10 and III-12) also developed mild memory problems. All living family members refused the genetic test. Blood samples for genetic testing were collected from the proband patient.

Magnetic resonance imaging (MRI) of the brain revealed no atrophy or vascular ischemic lesion (Figure $7 \mathrm{~b}$ ), but mild bitemporal hypometabolism in 18F fluorodeoxyglucose-Positron Emission Tomography (FDG-PET, Figure 7c) was suggested. Laboratory screening was negative for vasculitic, metabolic, or infectious causes. After three years, her symptoms progressed to more memory loss, ADL impairment, visual hallucination and dressing apraxia. Her physical activity was still intact, being able to walk and do simple household tasks. Her K-MMSE score declined to 19/30, clinical dementia rating scale of 1 (sum of boxes 8 ) and global deterioration scale score was 5 (moderate cognitive decline).

\subsection{Genetic Analysis}

The study was approved by the institutional review boards of the Korea University Guro Hospital and Ewha Woman's University Mokdong Hospital (13-21A-06; 03 July 2013). Written informed consents were obtained from all patients (or their caregivers) who participated in the study.

Blood samples of patients were centrifuged at $800 \times \mathrm{g}$ for a $30 \mathrm{~min}$, followed by the isolation of white blood cells (Buffy coat). DNA was purified by GeneAll blood kit (Seoul, Republic of Korea), and kept at $-20{ }^{\circ} \mathrm{C}$. Standard sequencing was performed for APP exon 16 and 17 [35,36], and for the coding region (exon 3-12) of PSEN1 and PSEN2 [21,37] genes. In addition, the coding regions of PRNP [38], PGRN [39] and MAPT [40] genes were also screened for pathogenic mutations. Before sequencing, polymerase chain reaction (PCR) products were purified by Expin PCR kit (Seoul, Republic of Korea). Sequencing was performed by BioNeer Inc. company (Dajeon, Republic of Korea). BigDye Terminator Cycle Sequencing kit (Seoul, Republic of Korea) was used for the sequencing reactions and ABI 3730XL DNA Analyzer was used to screen the chromatogramms (Bioneer Inc., Dajeon, Korea). Sequences were aligned by NCBI BLAST (http://blast.ncbi.nlm.nih.gov/Blast.cgi) and screened with DNA Baser software (http://www.dnabaser.com). Mutations and sequence mutations were identified and compared against the NCBI Gene (http:/ / www.ncbi.nlm.nih.gov/gene) and UniProt (http:/ / www.uniprot.org) databases. Mutations were screened in Korean Reference Genome Database (KRGDB, http:/ /152.99.75.168/KRGDB/menuPages/intro.jsp), where 622 asymptomatic Korean individuals were screened by whole genome sequencing. Mutations were also checked in larger databases, such as 1000Genomes (http:/ / www.internationalgenome.org/) and Exome Aggregation Consortium (ExAC, http:/ / exac.broadinstitute.org/). 


\subsection{Single Strand Conformation Polymorphism (SSCP)}

PCR-SSCP was based on the different mobility of single stranded DNA in gel from the altered conformations due to the mutations in comparison with the wild type [41]. Formamide loading buffer was added to the PCR products (50:50), and incubated at $98^{\circ} \mathrm{C}$ for $10 \mathrm{~min}$, followed by cooling down on ice for $10 \mathrm{~min}$. Native $12 \%$ polyacrylamide gel electrophoresis (PAGE) was used for the analysis. The running time was $15-21 \mathrm{~h}$, at $100 \mathrm{~V}$, on ice with TBE running buffer. The differential bands were visualized by SYBR Gold staining by following the manufacturer's protocol (Invitrogen Inc. Boston, MA, USA).

\subsection{In Silico Screening and Structure Predictions}

Possible pathogenic nature of mutations could be analyzed using simple online software tools, such as PolyPhen2 (http://genetics.bwh.harvard.edu/pph2) [42], Sorting intolerant to tolerant (SIFT, http://sift.jcvi.org/) [43] or Protein Variation Effect Analyzer (PROVEAN, http:// provean.jcvi. org/index.php) [44]. ExPasy prediction was also performed based on different parameters, including hydrophobicity scores, bulkiness and polarity [45]. The 3D modeling of normal and mutant PSEN1 protein structures were performed by the Raptor X web server (http:/ / raptorx.uchicago.edu/) [46]. This protein structure prediction server produced the 3D protein structures based on the homology modeling from the given protein sequences. The normal and mutant PSEN1 protein sequence was aligned by Discovery Studio 3.5 Visualizer tool (Accelrys, San Diego, CA, USA).

\section{Conclusions}

In conclusion, our report confirmed that PSEN1 Thr116Ile mutation was causative of an autosomal dominant EOAD. In silico predictions were performed to estimate the possible role of mutation, and confirmed that it could disturb the HL-I loop, resulting in significant possible disturbances in $\gamma$ secretase functions.

Author Contributions: Conceptualization, All authors; Methodology, E.B. (genetics), V.V.G. (genetics), H.-M.L. (clinical), S.-B.K. (clinical) and J.H.J. (clinical); Software, E.B. (in silico predictions) and V.V.G. (in silico predictions); Validation, V.V.G., S.S.A.A and S.Y.K.; Formal Analysis, E.B. (genetics), V.V.G. (genetics), H.-M.L., S.-B.K. and J.H.J.; Investigation, S.S.A.A. and S.Y.K.; Resources, H.-M.L., S.-B.K., J.H.J., S.S.A.A. and S.Y.K.; Data Curation, S.S.A.A. and S.Y.K.; Writing-Original Draft Preparation, E.B. (genetics), H.-M.L. (clinical), S.-B.K. (clinical) and J.H.J. (clinical); Writing-Review \& Editing, V.V.G., S.S.A.A. and S.Y.K.; Visualization, All authors; Supervision, S.S.A.A. and S.Y.K.; Project Administration, S.S.A.A., and S.Y.K.; Funding Acquisition, S.S.A.A. and S.Y.K.

Funding: This research was supported by a National Research Foundation of Korea (NRF) Grants awarded by the Korean government (MEST, No. 2017R1A2B4012636 \& 2017R1C1B5017807).

Acknowledgments: Authors would like to express their gratitude to the proband patients and their family members for their time and support.

Conflicts of Interest: The authors declare no conflict of interest. The funders had no role in the design of the study; in the collection, analyses, or interpretation of data; in the writing of the manuscript, and in the decision to publish the results.

\section{References}

1. Bagyinszky, E.; Youn, Y.C.; An, S.S.; Kim, S.Y. The genetics of Alzheimer's disease. Clin. Interv. Aging 2014, 9, 535-551. [CrossRef] [PubMed]

2. Wolfe, M.S. Structure, mechanism and inhibition of gamma-secretase and presenilin-like proteases. Biol. Chem. 2010, 391, 839-847. [CrossRef] [PubMed]

3. Azarnia Tehran, D.; Kuijpers, M.; Haucke, V. Presynaptic endocytic factors in autophagy and neurodegeneration. Curr. Opin. Neurobiol. 2018, 48, 153-159. [CrossRef] [PubMed]

4. Di Fede, G.; Catania, M.; Morbin, M.; Rossi, G.; Suardi, S.; Mazzoleni, G.; Merlin, M.; Giovagnoli, A.R.; Prioni, S.; Erbetta, A.; et al. A recessive mutation in the APP gene with dominant-negative effect on amyloidogenesis. Science 2009, 323, 1473-1477. [CrossRef] [PubMed] 
5. Zou, Z.; Liu, C.; Che, C.; Huang, H. Clinical genetics of Alzheimer's disease. Biomed. Res. Int. 2014, 2014, 291862. [CrossRef] [PubMed]

6. Ertekin-Taner, N. Genetics of Alzheimer's disease: A centennial review. Neurol. Clin. 2007, 25, 611-667. [CrossRef] [PubMed]

7. Campion, D.; Flaman, J.M.; Brice, A.; Hannequin, D.; Dubois, B.; Martin, C.; Moreau, V.; Charbonnier, F.; Didierjean, O.; Tardieu, S.; et al. Mutations of the presenilin I gene in families with early-onset Alzheimer's disease. Hum. Mol. Genet. 1995, 4, 2373-2377. [CrossRef] [PubMed]

8. Campion, D.; Dumanchin, C.; Hannequin, D.; Dubois, B.; Belliard, S.; Puel, M.; Thomas-Anterion, C.; Michon, A.; Martin, C.; Charbonnier, F.; et al. Early-onset autosomal dominant Alzheimer disease: Prevalence, genetic heterogeneity, and mutation spectrum. Am. J. Hum. Genet. 1999, 65, 664-670. [CrossRef] [PubMed]

9. Xia, D.; Watanabe, H.; Wu, B.; Lee, S.H.; Li, Y.; Tsvetkov, E.; Bolshakov, V.Y.; Shen, J.; Kelleher, R.J. Presenilin-1 knockin mice reveal loss-of-function mechanism for familial Alzheimer's disease. Neuron 2015, 85, 967-981. [CrossRef] [PubMed]

10. Chávez-Gutiérrez, L.; Bammens, L.; Benilova, I.; Vandersteen, A.; Benurwar, M.; Borgers, M.; Lismont, S.; Zhou, L.; Van Cleynenbreugel, S.; Esselmann, H.; et al. The mechanism of $\gamma$-secretase dysfunction in familial Alzheimer disease. EMBO J. 2012, 31, 2261-2274. [CrossRef] [PubMed]

11. An, S.S.; Park, S.A.; Bagyinszky, E.; Bae, S.O.; Kim, Y.J.; Im, J.Y.; Park, K.W.; Park, K.H.; Kim, E.J.; Jeong, J.H.; et al. A genetic screen of the mutations in the Korean patients with early-onset Alzheimer's disease. Clin. Interv. Aging 2016, 11, 1817-1822. [CrossRef] [PubMed]

12. La Bella, V.; Liguori, M.; Cittadella, R.; Settipani, N.; Piccoli, T.; Manna, I.; Quattrone, A.; Piccoli, F. A novel mutation (Thr116Ile) in the presenilin 1 gene in a patient with early-onset Alzheimer's disease. Eur. J. Neurol. 2004, 11, 521-524. [CrossRef] [PubMed]

13. Raux, G.; Guyant-Marechal, L.; Martin, C.; Bou, J.; Penet, C.; Brice, A.; Hannequin, D.; Frebourg, T.; Campion, D. Molecular diagnosis of autosomal dominant early onset Alzheimer's disease: An update. J. Med. Genet. 2005, 42, 793-795. [CrossRef] [PubMed]

14. Wallon, D.; Rousseau, S.; Rovelet-Lecrux, A.; Quillard-Muraine, M.; Guyant-Maréchal, L.; Martinaud, O.; Pariente, J.; Puel, M.; Rollin-Sillaire, A.; Pasquier, F.; et al. The French series of autosomal dominant early onset Alzheimer's disease cases: Mutation spectrum and cerebrospinal fluid biomarkers. J. Alzheimers Dis. 2012, 30, 847-856. [CrossRef] [PubMed]

15. Romero, I.; Jorgensen, P.; Bolwig, G.; Fraser, P.E.; Rogaeva, E.; Mann, D.; Havsager, A.M.; Jørgensen, A.L. A presenilin-1 Thr116Asn substitution in a family with early-onset Alzheimer's disease. Neuroreport 1999, 10, 2255-2260. [CrossRef] [PubMed]

16. Tysoe, C.; Whittaker, J.; Xuereb, J.; Cairns, N.J.; Cruts, M.; Van Broeckhoven, C.; Wilcock, G.; Rubinsztein, D.C. A presenilin-1 truncating mutation is present in two cases with autopsy-confirmed early-onset Alzheimer disease. Am. J. Hum. Genet. 1998, 62, 70-76. [CrossRef] [PubMed]

17. Dobricic, V.; Stefanova, E.; Jankovic, M.; Gurunlian, N.; Novakovic, I.; Hardy, J.; Kostic, V.; Guerreiro, R. Genetic testing in familial and young-onset Alzheimer's disease: Mutation spectrum in a serbian cohort. Neurobiol. Aging 2012, 33, 1481.e7-1481.e12. [CrossRef] [PubMed]

18. Finckh, U.; Kuschel, C.; Anagnostouli, M.; Patsouris, E.; Pantes, G.V.; Gatzonis, S.; Kapaki, E.; Davaki, P.; Lamszus, K.; Stavrou, D.; et al. Novel mutations and repeated findings of mutations in familial Alzheimer disease. Neurogenetics 2005, 6, 85-89. [CrossRef] [PubMed]

19. Raux, G.; Gantier, R.; Thomas-Anterion, C.; Boulliat, J.; Verpillat, P.; Hannequin, D.; Brice, A.; Frebourg, T.; Campion, D. Dementia with prominent frontotemporal features associated with L113P presenilin 1 mutation. Neurology 2000, 55, 1577-1578. [CrossRef] [PubMed]

20. Wisniewski, T.; Dowjat, W.K.; Buxbaum, J.D.; Khorkova, O.; Efthimiopoulos, S.; Kulczycki, J.; Lojkowska, W.; Wegiel, J.; Wisniewski, H.M.; Frangione, B. A novel Polish presenilin-1 mutation (P117L) is associated with familial Alzheimer's disease and leads to death as early as the age of 28 years. Neuroreport 2008, 9, $217-221$. [CrossRef]

21. Cruts, M.; van Duijn, C.M.; Backhovens, H.; Van den Broeck, M.; Wehnert, A.; Serneels, S.; Sherrington, R.; Hutton, M.; Hardy, J.; St George-Hyslop, P.H.; et al. Estimation of the genetic contribution of presenilin-1 and -2 mutations in a population-based study of presenile Alzheimer disease. Hum. Mol. Genet. 1998, 7, 43-51. [CrossRef] [PubMed] 
22. Poorkaj, P.; Sharma, V.; Anderson, L.; Nemens, E.; Alonso, M.E.; Orr, H.; White, J.; Heston, L.; Bird, T.D.; Schellenberg, G.D. Missense mutations in the chromosome 14 familial Alzheimer's disease presenilin 1 gene. Hum. Mutat. 1998, 11, 216-221. [CrossRef]

23. Anheim, M.; Hannequin, D.; Boulay, C.; Martin, C.; Campion, D.; Tranchant, C. Ataxic variant of Alzheimer's disease caused by Pro117Ala PSEN1 mutation. J. Neurol. Neurosurg. Psychiatry 2007, 78, 1414-1415. [CrossRef] [PubMed]

24. Yasuda, M.; Maeda, K.; Hashimoto, M.; Yamashita, H.; Ikejiri, Y.; Bird, T.D.; Tanaka, C.; Schellenberg, G.D. A pedigree with a novel presenilin 1 mutation at a residue that is not conserved in presenilin 2. Arch. Neurol. 1999, 56, 65-69. [CrossRef] [PubMed]

25. Gong, P.; Vetrivel, K.S.; Nguyen, P.D.; Meckler, X.; Cheng, H.; Kounnas, M.Z.; Wagner, S.L.; Parent, A.T.; Thinakaran, G. Mutation analysis of the presenilin $1 \mathrm{~N}$-terminal domain reveals a broad spectrum of gamma-secretase activity toward amyloid precursor protein and other substrates. J. Biol. Chem. 2010, 285, 38042-38052. [CrossRef] [PubMed]

26. Winblad, B.; Kosik, K.; Haltia, M.; Poyhonen, M.; Dickson, D.; Mann, D.; Neary, D.; Snowdon, J.; Lantos, P.; Lannfelt, L.; et al. The structure of the presenilin 1 (S182) gene and identification of six novel mutations in early onset AD families. Nat. Genet. 1995, 11, 219-222.

27. Takagi-Niidome, S.; Sasaki, T.; Osawa, S.; Sato, T.; Morishima, K.; Cai, T.; Iwatsubo, T.; Tomita, T. Cooperative roles of hydrophilic loop 1 and the C-terminus of presenilin 1 in the substrate-gating mechanism of $\gamma$-secretase. J. Neurosci. 2015, 35, 2646-2656. [CrossRef] [PubMed]

28. Jiao, B.; Tang, B.; Liu, X.; Xu, J.; Wang, Y.; Zhou, L.; Zhang, F.; Yan, X.; Zhou, Y.; Shen, L. Mutational analysis in early-onset familial Alzheimer's disease in Mainland China. Neurobiol. Aging 2014, 35, 1957.e1-1957.e6. [CrossRef] [PubMed]

29. Campion, D.; Flaman, J.M.; Brice, A.; Hannequin, D.; Dubois, B.; Martin, C.; Moreau, V.; Charbonnier, F.; Didierjean, O.; Tardieu, S. Mutations of the presenilin I gene in families with early-onset Alzheimer's disease. Hum. Mol. Genet. 1995, 4, 2373-2377. [CrossRef] [PubMed]

30. Zekanowski, C.; Styczyńska, M.; Pepłońska, B.; Gabryelewicz, T.; Religa, D.; Ilkowski, J.; Kijanowska-Haładyna, B.; Kotapka-Minc, S.; Mikkelsen, S.; Pfeffer, A.; et al. Mutations in presenilin 1, presenilin 2 and amyloid precursor protein genes in patients with early-onset Alzheimer's disease in Poland. Exp. Neurol. 2003, 184, 991-996. [CrossRef]

31. Dowjat, W.K.; Wisniewski, T.; Efthimiopoulos, S.; Wisniewski, H.M. Inhibition of neurite outgrowth by familial Alzheimer's disease-linked presenilin-1 mutations. Neurosci. Lett. 1999, 267, 141-144. [CrossRef]

32. Lladó, A.; Sánchez-Valle, R.; Rey, M.J.; Mercadal, P.; Almenar, C.; López-Villegas, D.; Fortea, J.; Molinuevo, J.L. New mutation in the PSEN1 (E120G) gene associated with early onset Alzheimer's disease. Neurologia 2010, 25, 13-16. [CrossRef]

33. Hutton, M.; Busfield, F.; Wragg, M.; Crook, R.; Perez-Tur, J.; Clark, R.F.; Prihar, G.; Talbot, C.; Phillips, H.; Wright, K.; et al. Complete analysis of the presenilin 1 gene in early onset Alzheimer's disease. Neuroreport 1996, 7, 801-805. [CrossRef] [PubMed]

34. Ryan, N.S.; Nicholas, J.M.; Weston, P.S.J.; Liang, Y.; Lashley, T.; Guerreiro, R.; Adamson, G.; Kenny, J.; Beck, J.; Chavez-Gutierrez, L.; et al. Clinical phenotype and genetic associations in autosomal dominant familial Alzheimer's disease: A case series. Lancet. Neurol. 2016, 15, 1326-1335. [CrossRef]

35. Schellenberg, G.D.; Pericak-Vance, M.A.; Wijsman, E.M.; Moore, D.K.; Gaskell, P.C.; Yamaoka, L.A.; Bebout, J.L.; Anderson, L.; Welsh, K.A.; Clark, C.M.; et al. Linkage analysis of familial Alzheimer disease, using chromosome 21 markers. Am. J. Hum. Genet. 1991, 48, 563-583. [PubMed]

36. Tanzi, R.E.; Vaula, G.; Romano, D.M.; Mortilla, M.; Huang, T.L.; Tupler, R.G.; Wasco, W.; Hyman, B.T.; Haines, J.L.; Jenkins, B.J.; et al. Assessment of amyloid $\beta$-protein precursor gene mutations in a large set of familial and sporadic alzheimer disease cases. Am. J. Hum. Genet. 1992, 51, 273-282. [PubMed]

37. Kamimura, K.; Tanahashi, H.; Yamanaka, H.; Takahashi, K.; Asada, T.; Tabira, T. Familial Alzheimer's disease genes in Japanese. J. Neurol. Sci. 1998, 160, 76-81. [CrossRef]

38. Jeong, B.H.; Ju, W.K.; Huh, K.; Lee, E.A.; Choi, I.S.; Im, J.H.; Choi, E.K.; Kim, Y.S. Molecular analysis of prion protein gene (PRNP) in Korean patients with Creutzfeldt-Jakob disease. J. Korean Med. Sci. 1998, 13, $234-240$. [CrossRef] [PubMed] 
39. Cruts, M.; Gijselinck, I.; van der Zee, J.; Engelborghs, S.; Wils, H.; Pirici, D.; Rademakers, R.; Vandenberghe, R.; Dermaut, B.; Martin, J.J.; et al. Null mutations in progranulin cause ubiquitin-positive frontotemporal dementia linked to chromosome 17q21. Nature 2006, 442, 920-924. [CrossRef] [PubMed]

40. Rizzu, P.; Van Swieten, J.C.; Joosse, M.; Hasegawa, M.; Stevens, M.; Tibben, A.; Niermeijer, M.F.; Hillebrand, M.; Ravid, R.; Oostra, B.A.; et al. High prevalence of mutations in the microtubule-associated protein tau in a population study of frontotemporal dementia in the Netherlands. Am. J. Hum. Genet. 1999, 64, 414-421. [CrossRef] [PubMed]

41. Hayashi, K. PCR-SSCP: A simple and sensitive method for detection of mutations in the genomic DNA. PCR Methods Appl. 1991, 1, 34-38. [CrossRef] [PubMed]

42. Adzhubei, I.A.; Schmidt, S.; Peshkin, L.; Ramensky, V.E.; Gerasimova, A.; Bork, P.; Kondrashov, A.S.; Sunyaev, S.R. A method and server for predicting damaging missense mutations. Nat. Methods. 2010, 7 , 248-249. [CrossRef] [PubMed]

43. Ng, P.C.; Henikoff, S. SIFT: Predicting amino acid changes that affect protein function. Nucleic Acids Res. 2003, 31, 3812-3814. [CrossRef] [PubMed]

44. Choi, Y.; Sims, G.E.; Murphy, S.; Miller, J.R.; Chan, A.P. Predicting the functional effect of amino acid substitutions and indels. PLOS ONE 2012, 7, e46688. [CrossRef] [PubMed]

45. Gasteiger, E.; Gattiker, A.; Hoogland, C.; Ivanyi, I.; Appel, R.D.; Bairoch, A. ExPASy: The proteomics server for in-depth protein knowledge and analysis. Nucleic Acids Res. 2003, 31, 3784-3788. [CrossRef] [PubMed]

46. Källberg, M.; Wang, H.; Wang, S.; Peng, J.; Wang, Z.; Lu, H.; Xu, J. Template-based protein structure modeling using the RaptorX web server. Nat. Protoc. 2012, 7, 1511-1522. [CrossRef] [PubMed]

(C) 2018 by the authors. Licensee MDPI, Basel, Switzerland. This article is an open access article distributed under the terms and conditions of the Creative Commons Attribution (CC BY) license (http:/ / creativecommons.org/licenses/by/4.0/). 